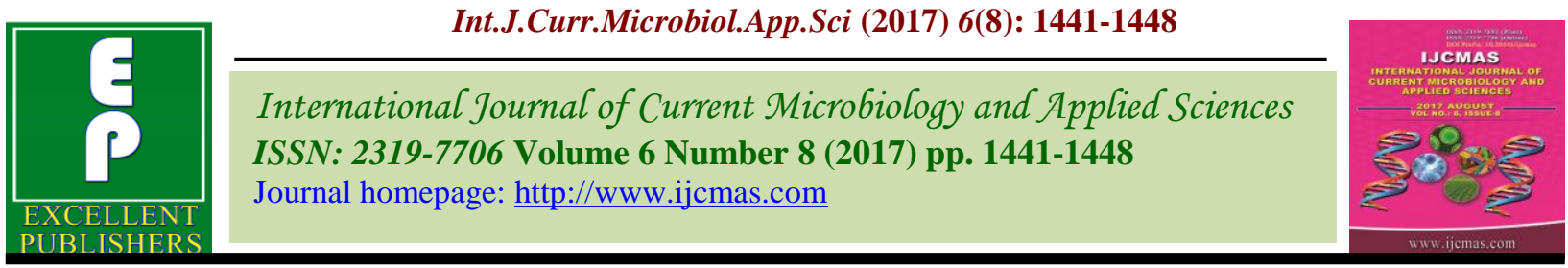

Original Research Article

https://doi.org/10.20546/ijcmas.2017.608.174

\title{
Evaluation of Pest Management Strategies against Sucking Insect-Pests for the Safety of Beneficial Insects in Vegetable French bean (Phaseolus vulgaris L.)
}

\author{
Amit Mondal, Uma Shankar*, D.P. Abrol, Ichpal Singh and Thanlass Norboo
}

\begin{abstract}
Division of Entomology, Faculty of Agriculture, Sher-e-Kashmir University of Agricultural Sciences and Technology of Jammu, Chatha, Jammu-180009, J\&K, India

*Corresponding author
\end{abstract}

\begin{tabular}{|l|}
\hline Ke y w or d s \\
Sucking insect- \\
pests, Aphids, \\
mites, French bean, \\
Phseolus vulgaris, \\
Beneficial insects, \\
IPM modules. \\
\hline Article Info \\
\hline Accepted: \\
17 June 2017 \\
Available Online: \\
10 August 2017 \\
\hline
\end{tabular}

A B S T R A C T

Field experiments were conducted to evaluate the pest management strategies against sucking insect-pests for the safety of beneficial insects in vegetable French bean (Phaseolus vulgaris L.) during rabi 2013 at SKUAST-Jammu. French bean crop is ravaged by wide array of insect pests wherein, sucking insect-pests like aphids and mites causing considerable damage. Three different IPM modules viz., Module-I (Deep ploughing, Cabofuran 3G@25 kg/ha, Pheromone traps@20/ha, Spinosad 48 SC@1\%, Indoxacarb14.5 SC @0.05 \%), Module-II (Deep ploughing, Cabofuran 3G@ $25 \mathrm{~kg} / \mathrm{ha}$, Delta traps@100/ha, Bacillus thuringiensis var. kurstaki, 90-120 billion spores /g@ 500g per hectare, Imidacloprid 17.8 SL @0.05 \%) and Module-III (Deep ploughing, Cabofuran 3G@ 25 kg/ha, Fruit fly traps@50/ha, Beauvaria bassiana@1.2 $\times 10^{13}$ conidia/ha, Thiomethoxam 25WG @0.1\%) were evaluated in comparison with the farmer's practice and control plot to manage the pests in an eco-friendly manner. Among the modules tested, Module-II was found to be the best treatment for controlling the bean aphids and safer for the aphids parasitoids in parasitzing the aphids population while, Module-III was found to be the best in suppressing the mite population and quite safe for maintaining the predators like Chrysoperla carnea for natural predation.

\section{Introduction}

Legumes are grown in tropical and subtropical countries of the world which constitute an important food source for humans and animals (Graham and Vance, 2003) and add a positive impact on agriculture and the environment (Uebersax 2006). Among legumes, French bean (Phaseolus vulgaris L.) (Leguminosae: Fabacea), commonly known as Rajmash in Jammu and Kashmir state, is gaining popularity in the Indian plain due to its high yield potential (2.5 to 3.5 tonnes per ha). They are considered to be most widely grown among more than 30 Phaseolus species and suitable for a wide range of environments (Hidalgo, 1988). In recent years, the growing concern of human metabolic disorders has aroused the significant interest in therapeutic uses of legumes. Due to high protein content (21.1\%), French bean plays a strategic role against protein calorie malnutrition in India (Kumar et al., 2006) and reducing the risk of chronic disease (Raju and Mehta, 2009) in developing countries (Van Heerden and Schonfeldt, 2004). The world production of dry beans have increased significantly higher 
(5.6 million MT) and recorded to 23.2 million metric tons (MT) in 2010. India is the largest producer and consumer of pulses in the world, accounting for $33 \%$ of the world area and $20 \%$ of the world production. In Jammu and Kashmir, the area under beans vegetable cultivation is 118000 hectare with an estimated annual production of 1151000 tonnes during the year 2011-12 (Anonymous, 2013).

Leguminous plant species are susceptible to many biotic stresses, including attacks by many different insect pests and diseases. Pest and disease problems are the major constraints to agricultural productivity of the common bean, particularly in the tropics (Graham and Vance, 2003). Worldwide, yield losses due to insect pests alone have been estimated to the tune of $35 \%$ to $100 \%$ annually (Singh and Schwartz, 2011). One of the major constraints in the production of French bean is the attack of vast array of insect pests such as pod borers, spotted pod borer, spiny pod borer, pod fly, leaf miner, stem fly, bean weevil, aphids, white fly, defoliators, mites, thrips which cause considerable economic damage (Rizvi and Singh, 1994; Srivastava and Agarwal, 2004; Sharma et al., 2005; Oyewale and Bamaiyi, 2013). More than 37 morpho species of arthropod insect pests were associated with French bean crop in the Jammu region (Uma Shankar, personal communication). In some locations in Jammu and Kashmir, there had been a complete failure of the crop whereas, in other places losses to the tune of $90-95 \%$ have been noticed (Abrol et al., 2006).

Economic significance of the French bean crops compelled the vegetable growers to use more frequent insecticide applications of recommended and non-recommended chemicals for suppressing the insect pest population which led to the elimination of beneficial insects. In agronomic systems, beneficial insects especially parasitoids, predators and pollinators contribute to enhance the ecological stability of the cropping system and thereby increasing the crop yield (Nuessly et al., 2004; Landis et al., 2005; Kasina et al., 2006). In recent years, pest management strategies receiving greater attention of the pest management workers throughout the world for their utilization as eco-friendly and sustainable and hence there is a need to develop Integrated Pest Management modules for the safer and healthier production of vegetable crops.

\section{Materials and Methods}

Based on the effectiveness of treatments, the different Integrated Pest Management modules were evaluated for their efficacy against sucking insect pests and their beneficial insects in French bean, Phaseolus vulgaris field during 2013. Three different modules were tested and compared with the farmer's practice including one control for managing sucking insect pests like aphids and mites /beneficial insects. They are as follows-

The experiment containing 5 treatments including one control, farmer's practice and three IPM modules were conducted in randomized block design with four replications. Observations were taken at weekly intervals starting from 15 days after transplanting or appearance of insect pests till the harvest of the crop. The French bean variety Local was sown with a spacing of $60 \mathrm{x}$ $45 \mathrm{~cm}$ in 4 and $3 \mathrm{~m}$ plots. The experimental plots received all the recommended packages except plant protection measures at vegetative stage of the crop growth. The total number of plants infested with the aphids and mites insect-pests was recorded at vegetative stage, $50 \%$ flowering stage and $50 \%$ pod setting stage after crop emergence in each plot and per cent mean infestation was worked out. In each modules, two sprayings were given i.e., 
one at vegetative stage as blanket spray and other were synchronized with the peak insectpest population just before the flowering. Critical difference for treatments was computed at 5 per cent level of significance. For comparing the data sets, we used the Post hoc data analysis in Tukey HSD test. Statistical analysis was done by using SPSS16 Software.

\section{Results and Discussion}

The experimental results on impact of different IPM modules on mean number of beneficial insect's population during 2013 for the managements of bean aphids and mites in the present studies are presented in tables 1 and 2, respectively. The data presented in table 1 showed the impact of different IPM Modules on mean aphid population on three different timings viz., at vegetative stage, at $50 \%$ flowering stage and at $50 \%$ pod setting stage. The corresponding mean number of aphid mummies populations were also recorded at different stages in different treatments and compared with the data collected from the farmers' field and control plot.

At vegetative stage, the mean number of aphids population in Module -II was found to be lowest (58.00 mean number of aphids population) which was significantly different $(\mathrm{P}<0.05)$ from module-III, Module-I and farmer' practice. Similar findings were also observed at $50 \%$ flowering (62.75 mean number of aphids population) and at $50 \%$ pod setting stage (42.00 mean number of aphids population) which showed that the Module -II was significantly different in suppressing the mean number of aphids population rather than other modules and farmers' practice. The module-I had (60.25 mean number of aphids population) and Module -III had 49.75 mean number of aphids population and both the treatments were found significantly different from farmers' practice and control.

When comparing the value obtained in different stages, the maximum mean number of aphid mummies population were recorded as $20.25,28.75$ and 18.50 at vegetative, at 50 $\%$ flowering and at $50 \%$ pod setting stage, respectively. At flowering stage, Module-II was found to be at par in significance with Module-III while at $50 \%$ pod setting stage Module-I and Module-III was at par but significantly different from Module-II. Overall, the data reflects that the module-II having $B t$ and imidacloprid treatment were proved to be safer for the beneficial insects like aphids parasitoid in parasitizing the live aphids in the field condition.

The overall mean impact of IPM modules after implementing the modules having two spraying (with chemical inputs- one at vegetative stage as blanket spray and other was synchronized with the peak insect pest population just before the flowering) revealed the following descending order of performance of treatments was as follows:

Module-II > Module-III >Module-I $>$ Farmers' practice $>$ Control.

While, in case of impact of different Integrated Pest Management Modules on mean mites pest population on three different timings viz., at vegetative stage, at $50 \%$ flowering stage and at $50 \%$ pod setting stage during 2013, the mean number of mites population and mean number of Chrysoperla carnea grubs are presented in table 2. Adults and grubs of Chrysoperla carnea is the predatory in nature and they have been established predators of sucking pests like mites, and aphids.

At vegetative stage, minimum mean number of mites population was observed in ModuleIII (5.00) followed by Module-II (7.00), Farmers' practice (7.50), module-II (8.5) and control (9.00). 
Table.1 Evaluation of different IPM Modules against aphids and their impact on beneficial insects on French bean

\begin{tabular}{|c|c|c|c|c|c|c|c|}
\hline $\begin{array}{l}\text { S. } \\
\text { No. }\end{array}$ & Different types of IPM Modules & $\begin{array}{l}\text { Aphid mean } \\
\text { population at } \\
\text { vegetative } \\
\text { stage }\end{array}$ & $\begin{array}{l}\text { Aphid mean } \\
\text { population at } \\
50 \% \\
\text { flowering } \\
\text { stage }\end{array}$ & $\begin{array}{l}\text { Aphid mean } \\
\text { population at } \\
50 \% \text { pod } \\
\text { setting stage }\end{array}$ & $\begin{array}{l}\text { Aphid } \\
\text { mummies } \\
\text { population at } \\
\text { vegetative } \\
\text { stage }\end{array}$ & $\begin{array}{l}\text { Aphid mummies } \\
\text { population at } 50 \\
\% \text { flowering } \\
\text { stage }\end{array}$ & $\begin{array}{l}\text { Aphid } \\
\text { mummies } \\
\text { population at } \\
50 \% \text { pod } \\
\text { setting stage }\end{array}$ \\
\hline 1 & $\begin{array}{l}\text { Module-I } \\
\text { (Deep ploughing+Carbofuran } \\
\text { 3G+Pheromone traps @ } 20 \\
\text { /ha+Spinosad 48 SC@ } 0.2 \\
\text { g/l+Indoxacarb14.5 SC @ } 0.3 \mathrm{ml} / \mathrm{l} \text { ) }\end{array}$ & $72.50 \mathrm{c}$ & $80.75 b c$ & $60.25 \mathrm{c}$ & $11.25 \mathrm{dc}$ & $18.00 \mathrm{c}$ & $13.75 \mathrm{~d}$ \\
\hline 2 & $\begin{array}{l}\text { Module-II } \\
\text { (Deep ploughing+Carbofuran } \\
\text { 3G+Delta traps@ 100/ha+ } \\
\text { Bacillus thuringiensis var. kurstaki, } \\
\text { 90-120 billion spores /g @ 500g } \\
\text { per hectare +Imidacloprid } 17.8 \mathrm{SL} \\
@ 0.3 \mathrm{ml} / \mathrm{l} \text { ) }\end{array}$ & $58.00 \mathrm{e}$ & $62.75 \mathrm{e}$ & $42.00 \mathrm{a}$ & $20.25 \mathrm{e}$ & $28.75 \mathrm{e}$ & $18.50 \mathrm{e}$ \\
\hline 4 & $\begin{array}{l}\text { Farmers Practice (Cultural } \\
\text { method+Intensive Chemical } \\
\text { Control methods) }\end{array}$ & $80.50 \mathrm{ab}$ & $83.25 b$ & $63.25 \mathrm{ed}$ & $7.75 b$ & $11.50 \mathrm{~b}$ & $5.75 b$ \\
\hline 5 & Control (Untreated) & $85.00 \mathrm{a}$ & $89.25 \mathrm{a}$ & $69.00 \mathrm{e}$ & $3.50 \mathrm{a}$ & $6.00 \mathrm{a}$ & $2.50 \mathrm{a}$ \\
\hline
\end{tabular}

Tukey HSD test;

Means within the column followed by different letters are significantly different $\mathrm{P}<0.05$ 
Table.2 Evaluation of different IPM Modules against mites and their impact on Chrysoperla carnea on French bean

\begin{tabular}{|c|c|c|c|c|c|c|c|}
\hline $\begin{array}{l}\text { S. } \\
\text { No. }\end{array}$ & Different types of IPM Modules & $\begin{array}{l}\text { Mites mean } \\
\text { population } \\
\text { at vegetative } \\
\text { stage }\end{array}$ & $\begin{array}{l}\text { Mites mean } \\
\text { population at } \\
50 \% \\
\text { flowering } \\
\text { stage }\end{array}$ & $\begin{array}{l}\text { Mites mean } \\
\text { population at } \\
50 \% \text { pod } \\
\text { setting stage }\end{array}$ & $\begin{array}{l}\text { Chrysoperla } \\
\text { carnea } \\
\text { population at } \\
\text { vegetative } \\
\text { stage }\end{array}$ & $\begin{array}{l}\text { Chrysoperla } \\
\text { carnea } \\
\text { population at } \\
50 \% \text { flowering } \\
\text { stage }\end{array}$ & $\begin{array}{l}\text { Chrysoperla } \\
\text { carnea } \\
\text { population at } \\
50 \% \text { pod } \\
\text { setting stage }\end{array}$ \\
\hline 1 & $\begin{array}{l}\text { Module-I } \\
\text { (Deep ploughing+Carbofuran } \\
\text { 3G+Pheromone traps @ } 20 \\
\text { /ha+Spinosad 48 SC@ } 0.2 \\
\text { g/l+indoxacarb14.5 SC @ } 0.3 \\
\text { ml/l) }\end{array}$ & 7.00edcb & $10.75 \mathrm{cb}$ & $10.50 \mathrm{dc}$ & $1.00 \mathrm{dcb}$ & $6.25 \mathrm{ed}$ & $3.25 \mathrm{ed}$ \\
\hline 2 & $\begin{array}{l}\text { Module-II } \\
\text { (Deep ploughing+Carbofuran } \\
\text { 3G+Delta traps@ 100/ha+ } \\
\text { Bacillus thuringiensis var. } \\
\text { kurstaki, 90-120 billion spores /g } \\
\text { @ 500g per hectare } \\
\text { +Imidacloprid17.8 SL @ } 0.3 \\
\text { ml/l) }\end{array}$ & $8.5 \mathrm{ed}$ & $10.75 \mathrm{dc}$ & $10.25 \mathrm{dcb}$ & $1.25 \mathrm{dc}$ & $5.50 \mathrm{edc}$ & $3.25 \mathrm{edc}$ \\
\hline 3 & $\begin{array}{l}\text { Module-III } \\
\text { (Deep ploughing+Carbofuran } \\
\text { 3G+Fruit fly traps@50/ha+ } \\
\text { Beauvaria bassiana @ } 1.2 \times 1013 \\
\text { conidia/ha+Thiomethoxam } \\
\text { 25WG @ } 0.2 \mathrm{~g} / \mathrm{l} \text { ) }\end{array}$ & $5.00 \mathrm{a}$ & $7.25 \mathrm{a}$ & $8.25 \mathrm{dcba}$ & $1.25 \mathrm{~d}$ & $7.25 \mathrm{e}$ & $6.25 \mathrm{e}$ \\
\hline 4 & $\begin{array}{l}\text { Farmers Practice (Cultural } \\
\text { method+Intensive Chemical } \\
\text { Control methods) }\end{array}$ & 7.5edc & $12.00 \mathrm{ed}$ & $12.25 \mathrm{~d}$ & $0.25 \mathrm{dcba}$ & $0.75 \mathrm{ba}$ & $1.50 \mathrm{ba}$ \\
\hline 5 & Control (Untreated) & $9.00 \mathrm{e}$ & $13.25 \mathrm{e}$ & $19.00 \mathrm{e}$ & $3.00 \mathrm{e}$ & $0.75 b$ & $1.50 \mathrm{~b}$ \\
\hline
\end{tabular}

Tukey HSD test

Means within the column followed by different letters are significantly different $\mathrm{P}<0.05$ 
Three different modules were tested and compared with the farmer's practice including one control for managing sucking insect pests like aphids and mites /beneficial insects

\begin{tabular}{|c|c|c|}
\hline Module-I & Module-II & Module-III \\
\hline Treatments & Treatments & Treatments \\
\hline 1. $\quad$ Deep ploughing & 1. $\quad$ Deep ploughing & 1. $\quad$ Deep ploughing \\
\hline Cabofuran3G@25 & $\begin{array}{l}\text { 2. } \quad \text { Cabofuran 3G@ } 25 \\
\mathrm{~kg} / \mathrm{ha}\end{array}$ & $\begin{array}{l}\text { 2. } \quad \text { Cabofuran 3G@ } 25 \\
\mathrm{~kg} / \mathrm{ha}\end{array}$ \\
\hline Pheromone traps@20 & Delta traps@ 100/ha & 3. $\quad$ Fruit fly traps@50/ha \\
\hline (0.2 g/l) & $\begin{array}{l}\text { 4. Bacillus thuringiensis } \\
\text { var. kurstaki, 90-120 billion } \\
\text { spores /g@ 500g per hectare }\end{array}$ & $\begin{array}{l}\text { 4. Beauvaria bassiana } \\
@ 1.2 \times 10^{13} \text { conidia/ha }\end{array}$ \\
\hline $\begin{array}{l}\text { 5. Indoxacarb14.5 SC } \\
@ 0.05 \%(0.3 \mathrm{ml} / \mathrm{l})\end{array}$ & $\begin{array}{l}\text { 5. Imidacloprid } 17.8 \mathrm{SL} \\
@ 0.05 \%(0.3 \mathrm{ml} / \mathrm{l})\end{array}$ & $\begin{array}{l}\text { 5. Thiomethoxam 25WG } \\
@ 0.1 \%(0.2 \mathrm{~g} / \mathrm{l})\end{array}$ \\
\hline
\end{tabular}

Here, module-III was found to be significantly different from other modules and treatments at $\mathrm{P}<0.05$. Again, the Module-III were recorded minimum number of mites population (7.25) at $50 \%$ flowering stage and found superior in controlling the mites population while, at $50 \%$ pod setting stage although the mean number of mites population was less (8.25) but the module is not significantly different from other modules and Farmers' practice except control.

Overall, the impact of Module-III was found to be best in reducing the number of mites' pest population and maintaining the balance of Chrysoperla carnea in the field condition. At the third stage of $50 \%$ pod setting stage, the maximum number of natural predator grubs number was found to be 6.25 which were significantly different from other modules. Module-I and Module-II were found to be at par in terms of safety of predators fauna in Phaseolus vulgaris field condition. After evaluating the modules against mites pests, the following descending order of performance of treatments was foundModule-III >Module-II > Module-I > Farmers' practice $>$ Control.

The impact of different IPM Modules on mean aphid pest population and the corresponding mean number of aphid mummies population and mean number of mites pest population and maintaining the balance of Chrysoperla carnea in the field condition were also recorded at different stages in different treatments and compared with the Post hoc data analysis in Tukey HSD test. The overall mean impact of IPM modules after implementing the modules having two spraying (with chemical inputs- one at vegetative stage as blanket spray and other was synchronized with the peak insect pest population just before the flowering) revealed that Module-II was found to be best for controlling the bean aphids and safer for the aphids parasitoids while, Module-III was found to be the best in suppressing the mite population and safer for maintaining the predators like Chrysoperla carnea against bean mites.

The present findings are in conformity with Kaniuczak and Matosz (1998) who revealed that new insecticide imidacloprid has considerable potential in faba bean IPM programs. Further, Parker and Biddle (1998) highlighted that the IPM in beans and advocated to minimize the broad-spectrum insecticides, more selective chemicals or biopesticides may be the possible substitute. French bean production in Jammu region 
suffers most from the damage caused by insect pest infestations in the field. The use of Integrated Pest Management modules is believed to be a promising strategy in controlling French bean pests in the field. With the adoption of IPM modules, farmers may reduce the pesticidal pressure on crops and effectively manage the sucking insectpests on French bean.

\section{Acknowledgments}

I acknowledge with thanks to the Professor \& Head for providing the necessary facilities at the Entomological Research Farm, SKUASTJ, Chatha.

\section{References}

Abrol, D. P., Ramamurthy, V. V. and Srivastava, K. 2006. Bean gall weevil and blister beetle as new pests on red kidney bean, Phaseolus vulgaris L. in India. Journal of Asia Pacific Entomology. 9 (4): 317-320.

Anonymous. 2013. State of Indian Agriculture 2012-13. Government of India, Ministry of Agriculture, Department of Agriculture and Cooperation, Directorate of Economics and Statistics, New Delhi.

Graham, P. H. and Vance, C. P. 2003. Legumes: Importance and Constraints to Greater Use.-Plant Physiology. 131: 872-877.

Kaniuczak, Z. and Matosz, I. 1998. The effect of insecticidal seed dressings upon the broad bean weevil (Bruchus rufimanus Boh.) in the cultivation of the field bean. Journal of Plant Protection Research. 38: 84-88.

Kasina, J. M., Nderitu, J. H., Nyamasyo, G. H. N., Olubayo, F., Waturu, C. N. and Obudho, E. 2006. Evaluation of companion crops for thrips (Thysanoptera:Thripidae) management in French beans Phaseolus vulgaris L. International Journal of Tropical Insect Science. 26: 121-125.

Kumar, R. P., Singh, O. N., Singh, Y. and Singh, J. P. 2006. Integrated nutrient management for quantitative and qualitative yield of french bean (Phaseolus vulgaris L.). Vegetable Science. 33(2): 155-159.

Landis, D. A., Menalled, F. D., Costamagna, A. C. and Wilkinson, T. K. 2005. Manipulating plant resources to enhance beneficial arthropods in agricultural landscapes. Weed Science. 53:902-908.

Nuessly, G. S., Hentz, M. G., Beiriger, R. and Scully, B. T. 2004. Insects associated with faba bean, Vicia faba (Fabales: Fabaceae), in Southern Florida. Florida Entomology. 87, 204-211.

Oyewale, R.O. and Bamaiyi, L. J. 2013. Management of cowpea insect pests. Scholars Academic Journal of Biosciences. 1(5):217-226.

Parker, W. E. and Biddle, A. J. 1998. Assessing the damage caused by black bean aphid (Aphis fabae) on spring beans. In: Proceedings of the Brighton Crop Protection Conference, Pests and Diseases. 3:1077-1082.

Raju, J. and Mehta, R. 2009. Cancer chemopreventive and therapeutic effects of diosgenin, a food saponin. Nuture and Cancer. 61: 27-35.

Rizvi, S. M. A. and Singh, A. K.1994. Succession of insect pests infesting Rajmash in eastern Uttar Pradesh. Indian Journal of Plant Protection. 22 (2):226-227.

Sharma, H. C., Clement, S. L., Ridsdill-Smith, T. J., Ranga Rao, G. V., El Bouhssini, M., Ujagir, R., Srivastava, C. P. and Miles, M. 2005. Insect pest management in food legumes: The future strategies. In: Proceedings of the Fourth International Food Legumes Research Conference, 18-22 Oct 2005, 
New Delhi, India.

Singh, S. P. and Schwartz, H. F. 2011.

Review: Breeding common bean for resistance to insectpests and nematodes. Canadian Journal of Plant Science. 91: 239-250.

Srivastava, C. and Agarwal, M. 2004. Relative toxicity of some insecticides to the adults of rajma beetle Zabrotes subfasciatus (Boh.). Indian Journal of Entomoogy. 66 (1): 40-41.
Uebersax, M. A. 2006. Dry Edible Beans: Indigenous Staple and Healthy Cuisine. Available online at http://forumonpublicpolicy.com/papersf 06.html\#nutrition (Accessed on May 7, 2014).

Van Heerden, S. M. and Schonfeldt, H. C. 2004. The need for food composition tables for Southern Africa. J. Food Compos. Anal. 17: 531-37.

\section{How to cite this article:}

Amit Mondal, Uma Shankar, D.P. Abrol, Ichpal Singh and Thanlass Norboo. 2017. Evaluation of Pest Management Strategies against Sucking Insect-Pests for the Safety of Beneficial Insects in Vegetable French Bean (Phaseolus vulgaris L.). Int.J.Curr.Microbiol.App.Sci. 6(8): 14411448. doi: https://doi.org/10.20546/ijcmas.2017.608.174 